\title{
Dynamic Programming Analysis for Measuring the Optimization of the Manpower per Shift PT. XYZ
}

\author{
Ida Rinjani $^{1^{*}}$, Sutrisno Sutrisno ${ }^{2}$, Billy Nugraha $^{3}$ \\ ${ }^{1,2,3}$ Industrial Engineering Department, Universitas Singaperbangsa Karawang, Karawang \\ *Koresponden email: idarinjani19@gmail.com
}

Diterima: 1 Februari 2021

Disetujui: 2 Maret 2021

\begin{abstract}
The problems that occur in the company is the production system make to order, for example PT. XYZ. Unknown certainty the amount of the order lenses will be produced. So it is not known how labor should be allocated to each shift. Then used the approach of dynamic programming to optimize the number of workers per shift in the PT. XYZ. This study aims to determine the analysis of the dynamic programming optimization to allocate the amount of labor per shift to be effective. The type of research data is primary data obtained through direct observation in PT. XYZ. The results of the research based on the calculation of the forward recursive dynamic programming: shift $1=105$ people, shift $2=104$ people and shift $3=$ 104 people. While the solution of the optimal allocation of labor for each shift based on the calculation of the backward recursive dynamic programming: shift $1=105$ people, shift $2=104$ people and Shift $3=$ 104 people. Then the PT. XYZ should allocate 313 workers, so that the allocation of labor to each shift is optimal according to the order received.
\end{abstract}

Keywords: dynamic programming, make to order, optimization, operational research, shift work

\begin{abstract}
Abstrak
Permasalahan yang terjadi di perusahaan adalah sistem produksi make to order, contohnya PT. XYZ. Belum diketahui kepastian jumlah pesanan lensa yang akan diproduksi sehingga tidak diketahui berapa tenaga kerja yang harus dialokasikan untuk setiap shiftnya. Maka digunakan pendekatan dynamic programming untuk mengoptimalkan jumlah pekerja per shift di PT. XYZ. Penelitian ini bertujuan untuk mengetahui analisis dynamic programming optimization untuk mengalokasikan jumlah tenaga kerja per shift menjadi efektif. Jenis data penelitian adalah data primer yang diperoleh melalui observasi langsung di PT. XYZ. Hasil penelitian berdasarkan perhitungan forward recursive dynamic programming: shift $1=$ 105 orang, shift $2=104$ orang dan shift $3=104$ orang. Sedangkan solusi optimal alokasi tenaga kerja untuk setiap shift berdasarkan perhitungan backward recursive dynamic programming: shift $1=105$ orang, shift $2=104$ orang dan Shift $3=104$ orang. Maka PT. XYZ harus mengalokasikan 313 pekerja, agar alokasi tenaga kerja untuk setiap shift optimal sesuai pesanan yang diterima.
\end{abstract}

Kata Kunci: dynamic programming, make to order, optimization, operational research, shift work

\section{Introduction}

Operations research seeks to determine the direction (best action) of an optimum decision problem under the limitation of limited resources [1]. In fact this problem was recognized by British scientists who pioneered the activities of the first OR during World War II. Although their work is primarily concerned with the optimum allocation of limited warfare resources, the group includes experts from fields such as sociology, psychology, and behavioral science in recognition of the importance of their contribution inconsiderate intangible factors in the decision-making process [2]. The model is an abstraction from the assumed real system and then identifies the appropriate relationships in the system in the form of goals and a group of constraints [3].

In the world of industry business competition is increasing and it is difficult [4]. In addition, with the increasing of another company that is superior. Then it became the main problem of the company to continue to perform optimal results [5]. In these conditions many companies are competing to be the best in their field. With increasing competition, of course, the company will improve the quality of management in order to compete and survive [6]. One of them is fixing the continuity of the production process. With the aim to meet the demand of consumers with timely and cost efficient production [7,8]. Therefore the company is required to work effectively in generating output and efficient use of inputs. Production is the primary function within the company that includes the activities of the production process. The production system has the components or elements of structural and functional at war 
significant to support the operational activities [9]. Dynamic programming optimization is a mathematical technique used to optimize the decision-making process gradually double [10]. Problems in decisionmaking multistage separated into sub-problems that relate to [11].

Dynamic Programming is a method of solving problems by breaking down a solution into a set of steps. So that, the solution to the problem can be viewed from a series of interrelated decisions [10]. Dynamic programming is one of the methods in mathematics which is useful to create a sequence of interrelated decisions, and provides a systematic procedure to determine the optimal combination of a decision [12]. Dynamic Programming is a powerful approach through which a global optimal solution can be obtained in the case of discrete solution space [2]. The concept of recursion consists of a recursive function and a recursive implementation it is a top-down approach [13]. This method has no standard formulation to solve the problem. There is something in common in every problem solving. The results of each stage will be the input for the next stage. In simple terms, the workings of the Dynamic Programming Method can be seen in Figure 1.

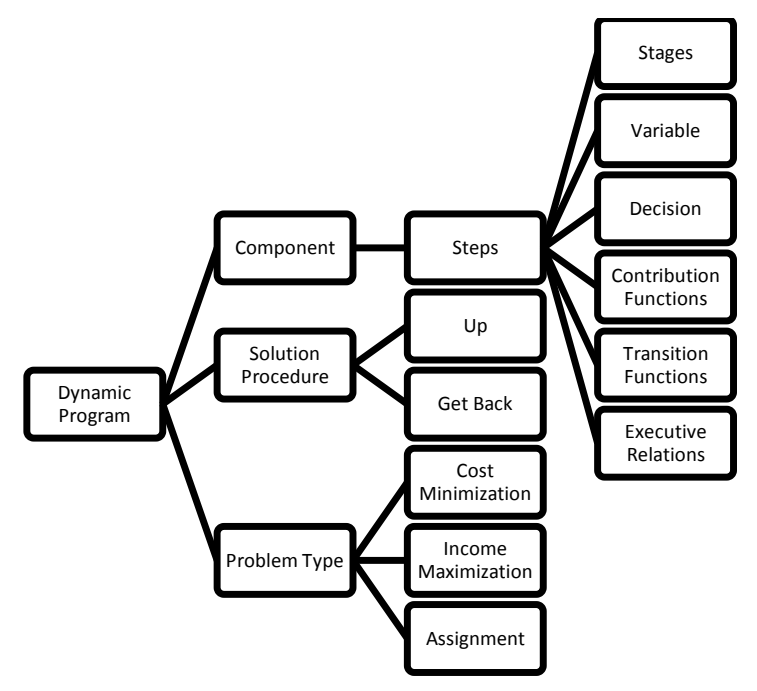

Figure 1. Dynamic programming method structure

Source: $[2,10]$

Dynamic programming is a mathematical technique that is usually used to make a decision from a series of interrelated decisions [13]. Dynamic programming was first developed by a scientist named Richard Bellman in 1957. In this case, dynamic programming provides a systematic procedure for determining the optimal combination of decisions. The main purpose of this model is to facilitate the resolution of optimization problems that have certain characteristics. In general, there are two types of dynamic programming methods, namely deterministic dynamic programming and probabilistic dynamic programming:

1. Dynamic program approach to deterministic problems, where the situation at the next stage is determined entirely by the circumstances and policy decisions at the current stage. At stage $n$ the process will be in a state $s n$. Policy decision making $x n$ then moves the process to the $s n+1$ state at stage $(n+1)$. The subsequent contribution to the objective function under optimal policy has been previously calculated as $f * n+1(s n+1)$. $x n$ policy decisions also contribute to the objective function. The correct combination of these two values will give $f n(S n, x n)$ which is $n$ 's future contribution to the objective function. Optimization against $x n$ gives $f n *(s n)=f n(s n, x n *)$. After finding $x n *$ and $f n *(s n)$ for each value $s n$, the settlement procedure now moves forward or back one step $[12,14]$.

2. Due to the existence of a probabilistic structure, the relationship between $f n$ ( $s n, x n)$ and $f n+1$ ( $s n$, $x n$ ) is slightly more complicated than for deterministic dynamic programming. The exact form of this relationship depends on the form of the objective function in general $[12,14]$.

\section{Literature Review}

Here are some previous studies which used as parameters in this study. The results of research conducted by Hermianus Yunus, Helmi and Shantika Martha: the Results obtained using dynamic programming with recursive advanced obtained based on the solution oprimal of iteration 1 [15]. The results of research conducted by Kana Saputra Saragih, Nur Hairiyah Harahap and Jufita Sari Sitorus: the Results of the 
research prove that the program can dynamically determine the optimal route for the 6 traditional market [16]. The results of research conducted by Ahmad Rizza Lufafi, Wiwik Yunarni Widiarti and Entin Hidayah: the Results of research using dynamic program to increase the profit from the harvest [17]. The results of research conducted by E. A. Rachma: Advantages of the program dynamic compared to the other method is to choose more than one making a series of decisions [18]. The results of research conducted by Novitasari and M. Imrom Mas'ud: From the results of the research resulted that using the method of dynamic programming is more profitable than ever before [19].

In addition, some research alternative that is used as a parameter in the study. The results of research conducted by Siti Maslihah: The result of research based on the average selling of crackers 9 berlian during the last three months. There is a $7.26 \%$ difference in the benefit of using a dynamic program of sales placements as usual $\left(\begin{array}{lll}2 & 2 & 2\end{array}\right.$ 3) [20]. The results of research conducted by Andi Rianata Brahmana, Poerwanto and Tuti Sarma Sinaga: The result of a total cost production optimal obtained by dynamic program by Rp.738.747.635.151, while the total cost of production actual companies in 2011 as much as Rp.748.716.706.550 [21]. The results of research conducted by Putri Delfianda, Hanny Komalig and Tohap Manurung: Based on the results of forecast using linear regression upcoming period May 2014 to April 2015. From of the cost of the dynamic program can be seen profits more than before using optimal dynamic program [22]. The results of research conducted by Wamiliana, Dian Kurniasari and Fatkur Rokhman: This paper will discuss about dynamic programming that applied in the determination of the minimum distance. Determination of the minimum distance will use an application to make it easier for calculation [23]. The results of research conducted by Diana Pratiwi, Syaripuddin and Haeruddin: To forecast the demand of amplang from December 2012 to Nopember 2013, it's used the ARIMA method with ARIMA $(0,1,1)$ model by purposing function: $Z_{t}=$ $\mathrm{Z}_{\mathrm{t}-1}-0,9628 \alpha_{\mathrm{t}-1}+\alpha_{\mathrm{t}}$ [24]. In previous studies, the stages in decision making were determining variables or $x 1$, $x 2, x 3$. So that the initial variable model for each stage (stage) can be used as follows:

$$
p i j(S n)
$$

Then after getting the calculation results based on statistical probability. Then calculated using Dynamic Program. Perform calculations using forward recursive, used mathematical notation as follows:

$$
f n *(s n, x n)=c n(x n)+f n-1 *(s n-x n)
$$

After that do the calculations using backward recursive, use the following mathematical notation:

$$
f n *(s n, x n)=c n(x n)+f n+1 *(s n-x n)
$$

Information:

$$
\begin{array}{ll}
f n *(s n, x n) & \text { shows the optimal contribution at stage } n . \\
c n(x n) & \text { amount of labor for the allocation of } x n \text { people to the } \\
& \text { shift }
\end{array}
$$

While the novelty in this study, before using dynamic programming. The first step is done the testing data using the Kolmogorov Smirnov Test. The results of the tests using the SPSS software version 23. After that, calculate using dynamic programming, do advanced recursive calculations, with the formula:

$$
f n *(s n, x n)=c n(x n)+f n-1 *(s n-x n)
$$

After that do the calculations using backward recursive, use the following mathematical notation:

$$
f n *(s n, x n)=c n(x n)+f n+1 *(s n-x n)
$$

\section{Research Methods}

The optimization and information systems fields are deemed suitable for use as the author's field of study, because the optimization field will look for problems, describe the problems. Besides finding the best or optimal solutions related to the object under study. In this case, the authors assess, the field of optimization is needed by manufacturing companies. This is because the company's production system is based on make to order, which requires a harmonious integration between work elements [13]. Both from the procurement of raw materials, procurement of labor, with the number of orders received [6]. This 
integration must produce a balanced composition of work elements. This is so that every order that comes to a manufacturing company can be produced properly according to the ability of the workforce (effective) and produce high profits with efficient production costs.

PT. XYZ was established in Karawang, West Java in 1991 on a land area of 25,000 m2 with a factory area: 15,000 m2. Labor owned by PT. XYZ as many as 311 manpower include male: 209 and female: 102. The method in this study uses a dynamic program method, which is applied to a manufacturing company engaged in the production of eyeglass lenses. This research was conducted with literature and field studies $[2,10]$. The data obtained are in the form of activities to produce eyeglass lenses. Based on the data obtained, dynamic programming analysis was carried out in order to measure the optimization of the number of workers per shift of PT. XYZ. In this research, the decisions made are multistage decision process or known as multiple step decisions. In which the optimal decision stage is the situation in each work shift which is practically divided into three work shifts, which means that there are three stages that must be passed in order to reach an optimal decision. In addition, this research will use dynamic programming methods backward (backward) and dynamic forward programming (forward).As for the troubleshooting steps in a dynamic program, as in Figure 2.

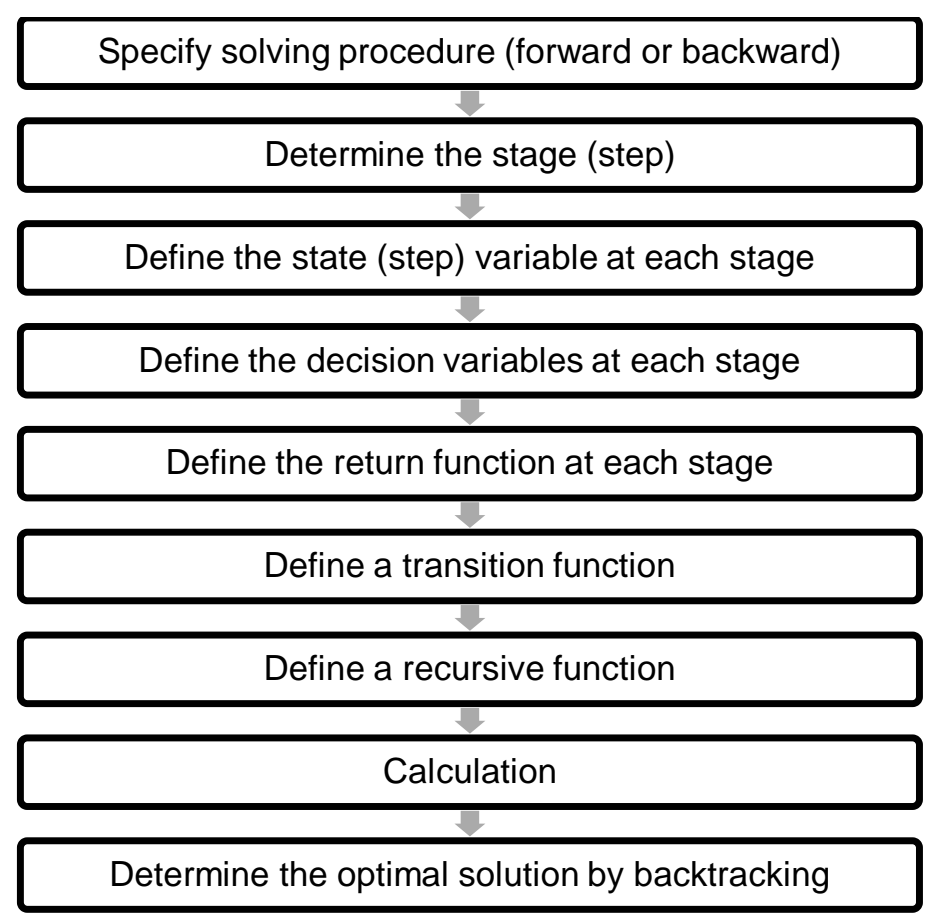

Figure 2.Research flow

\section{Assumptions Research Data}

Assumptions research data obtained from some of the results are the same. It can be used as a parameter for the determination of the variables/indicators to analyze the use of the method of dynamic programming. Then determine the variables/indicators of research to optimal results. However, before the method of dynamic programming, the data test the normality, namely the kolmogorov smirnov test with the SPSS software version 23.

\section{Preliminary Studies}

An initial study was conducted to determine how the groove until the result. The initial study is divided into two phases, namely the study of literacy and the field. Studies literacy conducted by the review process the results of the same study (using the method of dynamic programming). The field study was conducted at PT. XYZ as a case study in this research.

\section{Types of Research Data}

This research type is quantitative. This research was conducted by using the method of dynamic programming to determine the optimal results of the enterprise workforce. The subject of this research is some of the employees of the company by using the method of dynamic programming optimization. 


\section{Data Collection Techniques and Sampling}

Data collection techniques used is the study of the field. Field studies carried out gradually, starting from the interviews and documentation. In addition, the sampling technique in this research use purposive sampling.

\section{Data Analysis Techniques}

The data analysis technique used in this research is the concept of data analysis metode program dinamis optimisasi. In previous studies, the stages in decision making were determining variables or $x 1$, $x 2, x 3$. So that the initial variable model for each stage (stage) can be used as follows (1). Then after getting the calculation results based on statistical probability. Then calculated using Dynamic Program. Perform calculations using forward recursive, used mathematical notation as follows (2). After that do the calculations using backward recursive, use the following mathematical notation (3).

\section{Results and Discussion}

The data needed to become the source of this research is data regarding the number of lens orders within a month. This lens is the lens most ordered by customers. The actual data on the number of lens orders will be processed to determine the optimal number of workers in each shift. After obtaining the number of workers based on the number of lens orders, the data will then be processed using the Dynamic Programming method with forward recursive calculations and backward recursive calculations. So to get an optimal decision regarding the number of workers in each shift at PT. XYZ. In the forward recursive calculation, the first stage $(n=1)$ can be immediately assumed as the optimal state. Then the calculations for stage 2 and stage 3 can be calculated using a formula. Likewise with the backward recursive calculation, $(n=3)$ can be immediately assumed to be the optimal state, while for stages 2 and 1 it is done using the formula.

a. Data Collection, the data collected in this study is the number of lens orders in one month, namely data in January 2020. As well as data on the number of workers in January 2020. After the lens order data is available, then a data plot is made based on the number of working days at PT. XYZ as follows:

1) Monday = Group 1,

2) Tuesday = Group 2 ,

3) Wednesday $=$ Group 3 ,

4) Thursday = Group 4, and

5) Friday $=$ Group 5.

Meanwhile, the number of work shifts is as follows:

1) Shift 1:07.00 -15.30 WIB,

2) Shift 2: $15.30-23.00 \mathrm{WIB}$, and

3) Shift 3: $23.00-07.00$ WIB.

While the number of workers based on data taken in January 2020 amounted to 311 workers.

b. Data Normality Test, before entering the calculation and discussion stage, a data normality test must be carried out. This is about the distribution of the amount (arrival) data with the help of SPSS software to determine the type of data distribution. The results of the processing of the SPSS software are as shown in Table 1. The distribution according to the SPSS software is the Normal Distribution type. Because of Asymp. Sig. (2-tailed) $>0.025$ which means that $\mathrm{H} 0$ is accepted.

c. Data Processing, this problem requires making three interrelated decisions, namely how much labor to allocate to each shift. Thus, although there is no fixed sequence, these three shifts can be considered in a dynamic programming formula [25, 26]:

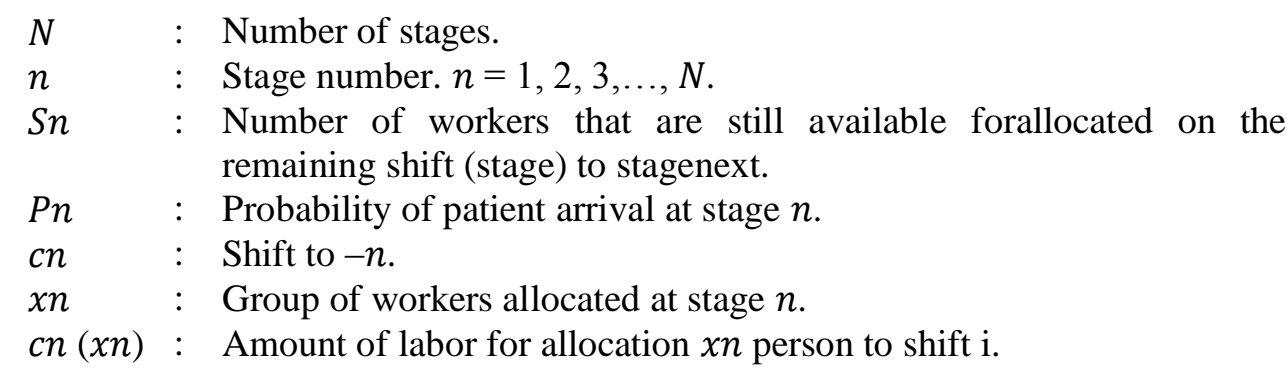


Table 1. Data normality test

\begin{tabular}{|c|c|c|c|}
\hline \multicolumn{4}{|c|}{ One-Sample Kolmogorov-Smirnov Test } \\
\hline \multirow[b]{2}{*}{$\mathrm{N}$} & Shift 1 & Shift 2 & Shift 3 \\
\hline & 5 & 5 & 5 \\
\hline \multirow{2}{*}{$\begin{array}{l}\text { Mean }^{\mathrm{a}, \mathrm{b}} \\
\text { Std Dev }^{\mathrm{a}, \mathrm{b}}\end{array}$} & 105.4000 & 103.8000 & 102.0000 \\
\hline & 1.14018 & 83666 & 1.8083 \\
\hline \multicolumn{4}{|c|}{ One-Sample Kolmogorov-Smirnov Test } \\
\hline \multirow[b]{2}{*}{$\mathrm{N}$} & Shift 1 & Shift 2 & Shift 3 \\
\hline & 5 & 5 & 5 \\
\hline Absolute & .237 & .231 & .300 \\
\hline Positive & .237 & .231 & .146 \\
\hline Negative & -.163 & -.194 & -.300 \\
\hline $\begin{array}{l}\text { Test Stat } \\
\text { Asymp. }\end{array}$ & .237 & .231 & .300 \\
\hline $\begin{array}{l}\text { Sig. } \\
\text { (2-tailed) }\end{array}$ & $.200^{\mathrm{c}, \mathrm{d}}$ & $.200^{\mathrm{c}, \mathrm{d}}$ & $.161^{\mathrm{c}}$ \\
\hline \multicolumn{4}{|c|}{$\begin{array}{lll}\text { a. } & : \text { Test distribution is Normal. } \\
\text { b. } & : \text { Calculated from data. } \\
\text { c. } & : \text { Lilliefors Significance Correction. } \\
\text { d. } & : \text { This is a lower bound of the true } \\
& \text { significance }\end{array}$} \\
\hline
\end{tabular}

The data on the number of lens orders per shift are accumulated from January 2020. The data shown in Table 2. is one month's accumulated data divided by the day. This data becomes data that can represent problems in dynamic programming. In this problem, it is wanted to achieve the maximum number of workers who can work so that the production process can run productively and optimally.

Table 2. Probability of number of lens orders per shift

\begin{tabular}{|c|c|c|c|c|}
\hline \multirow{2}{*}{ Day } & \multicolumn{3}{|c|}{ Probability } & \multirow{2}{*}{ Accumulation } \\
\hline & 1 & 2 & 3 & \\
\hline Monday & $33 \%$ & $33 \%$ & $33 \%$ & $100 \%$ \\
\hline Tuesday & $34 \%$ & $34 \%$ & $33 \%$ & $100 \%$ \\
\hline Wednesday & $34 \%$ & $33 \%$ & $33 \%$ & $100 \%$ \\
\hline Thursday & $34 \%$ & $34 \%$ & $32 \%$ & $100 \%$ \\
\hline Friday & $34 \%$ & $33 \%$ & $33 \%$ & $100 \%$ \\
\hline
\end{tabular}

Source: Research processing results, 2020

Furthermore, from Table 2, a plotting assumption of the number of workers is made by multiplying each probability of the number of lens orders per shift by the number of workers at PT. XYZ, amounting to 311 people. So from this calculation, data on the number of workers (Labor Plotting Results) will be obtained in accordance with the order of the lenses that come, as in Table 3.

Table 3. Number of shift workers based on number of lens orders

\begin{tabular}{lcccc}
\hline \multicolumn{1}{c}{ Day } & Morning & $\begin{array}{c}\text { Shift Workers } \\
\text { Afternoon }\end{array}$ & Evening & $\begin{array}{c}\text { Total } \\
\text { Workforce }\end{array}$ \\
\hline Monday & 104 & 104 & 104 & 311 \\
Tuesday & 105 & 104 & 102 & 311 \\
Wednesday & 105 & 103 & 103 & 311 \\
Thursday & 107 & 105 & 99 & 311 \\
Friday & 106 & 103 & 102 & 311 \\
\hline \multicolumn{5}{c}{ Source: Research processing results, 2020}
\end{tabular}

Which is based on Table 3. the problems in dynamic programming can be accumulated as a problem solving stage, as follows:

1) Stage $1=$ Workers working on shift 1 ,

2) Stage $2=$ Workers working on shift 2 , and 
3) Stage $3=$ Workers working on shift 3

And after the data is collected then it enters the calculation phase of the optimization of the workforce plots using the Dynamic Recursive Forward and Backward Recursive Programming methods, as follows:

1) Forward Recursive Settlement Procedure, done using forward recursive calculations. Then it will start from the first stage $(n=1)$. Because starting from the first stage, $n=1$, the optimum value for the first stage can be seen immediately by allocating all available $s 1$ to shift 1 :

a) Optimum Value for Stage $1(\mathrm{n}=1): f_{1}\left(S_{1}, X_{1}\right)=C_{1}\left(X_{1}\right)+f_{0}^{*}\left(S_{1}-X_{1}\right)$, in where [27, 28]:

$f_{0}^{*}\left(S_{1}-X_{1}\right)=0$, then it can be assumed:

$f_{0}^{*}\left(S_{1}-X_{1}\right)=C_{1}\left(X_{1}\right)$, so that:

$X_{1}^{*}=S_{1}$ and $f_{1}^{*}\left(S_{1}\right)=C_{1}\left(X_{1}\right)$.

Table 4. Completion of stage $1(\mathrm{n}=1)$ recursive forward

\begin{tabular}{ccc}
\hline S1 & F1 * (S1) & X1 \\
\hline 0 & 0 & 0 \\
1 & 104 & 1 \\
2 & 105 & 2 \\
3 & 105 & 3 \\
4 & 107 & 4 \\
5 & 106 & 5 \\
\hline
\end{tabular}

Source: Research processing results, 2020

Then the calculation moves forward starting from the previous stage $(\mathrm{n}=1)$. Here to determine $s 2$, it is necessary to calculate and compare $f 2(s 2, x 2)$ for alternative values of $x 2$, namely $s 2=0,1, \ldots, s 2[29]$.

b) Optimum Value for Stage $2(\mathrm{n}=2)$ :The calculations required for the $x 2$ case are summarized. The next calculation is continued for $S=4$ and $S=5$, until all calculations for the $n=2$ phase are complete, as in the accumulated calculation Table 5.

Table 5. Results of calculation stage 2 forward recursive

\begin{tabular}{|c|c|c|c|c|c|c|c|c|}
\hline \multirow{2}{*}{$\mathrm{S} / \mathrm{X} 2$} & \multicolumn{6}{|c|}{$\mathrm{F} 2(\mathrm{~S} 2, \mathrm{X} 2)-\mathrm{C} 2(\mathrm{X} 2)+\mathrm{F} 1(\mathrm{~S} 2-\mathrm{X} 2)$} & \multirow{2}{*}{$\mathrm{F} 2 *$} & \multirow{2}{*}{$\mathrm{X} 2 *$} \\
\hline & 0 & 1 & 2 & 3 & 4 & 5 & & \\
\hline 0 & $0+0=0$ & & & & & & 0 & 0 \\
\hline 1 & $0+104=104$ & $104+0=104$ & & & & & 104 & 0,1 \\
\hline 2 & $0+105=105$ & $104+104=208$ & $104+0=104$ & & & & 208 & 1 \\
\hline 3 & $0+105=107$ & $104+105=209$ & $104+104=208$ & $105+0=105$ & & & 209 & 1 \\
\hline 4 & $0+107=107$ & $104+105=209$ & $104+105=209$ & $103+104=207$ & $105+0=105$ & & 209 & 1,2 \\
\hline 5 & $0+106=106$ & $104+107=211$ & $104+105=209$ & $101+105=208$ & $105+104=209$ & $103+0=103$ & 211 & 1 \\
\hline
\end{tabular}

Source: Research processing results, 2020

c) Optimum Value of Stage $3(n=3)$ :The calculations required for the kasus 3 case are summarized. The next calculation is continued for $S=4$ and $S=5$, until all calculations for the $\mathrm{n}=3$ phase are complete, as in Table $\mathbf{6}$. the accumulated calculations below:

Table 6. Results of calculation stage 3 forward recursive

\begin{tabular}{|c|c|c|c|c|c|c|c|c|}
\hline \multirow{2}{*}{$\mathrm{S} / \mathrm{X} 2$} & \multicolumn{6}{|c|}{$\mathrm{F} 3(\mathrm{~S} 3, \mathrm{X} 3)-\mathrm{C} 3(\mathrm{X} 3)+\mathrm{F} 1(\mathrm{~S} 3-\mathrm{X} 3)$} & \multirow{2}{*}{$\mathrm{F} 2 *$} & \multirow{2}{*}{$\mathrm{X} 2 *$} \\
\hline & 0 & 1 & 2 & 3 & 4 & 5 & & \\
\hline 0 & $0+0=0$ & & & & & & 0 & 0 \\
\hline 1 & $0+104=104$ & $104+0=104$ & & & & & 104 & 0,1 \\
\hline 2 & $0+208=208$ & $104+104=208$ & $102+0=102$ & & & & 208 & 0,1 \\
\hline 3 & $0+209=209$ & $104+208=312$ & $102+104=206$ & $103+0=103$ & & & 312 & 1 \\
\hline 4 & $0+209=209$ & $104+209=313$ & $102+208=310$ & $103+104=207$ & $99+0=99$ & & 313 & 1 \\
\hline 5 & $0+211=211$ & $104+209=313$ & $102+209=311$ & $103+208=311$ & $99+104=203$ & $102+0=102$ & 313 & 1 \\
\hline
\end{tabular}

Source: Research processing results, 2020 
d) So based on the results of the calculation of the Advanced Recursive Dynamic Programming method, the accumulated results can be seen in Table 7.

Table 7. The accumulated result of forward recursive optimal solutions

\begin{tabular}{ccccccc}
\hline \multirow{2}{*}{$\mathrm{S}$} & \multicolumn{2}{c}{ Morning } & \multicolumn{2}{c}{ Afternoon } & \multicolumn{2}{c}{ Evening } \\
& $\mathrm{X} 1 *$ & $\mathrm{~F} 1 *(\mathrm{X} 1)$ & $\mathrm{X} 2 *$ & $\mathrm{~F} 2 *(\mathrm{X} 2)$ & $\mathrm{X} 3 *$ & $\mathrm{~F} 3 *(\mathrm{X} 3)$ \\
\hline 0 & 0 & 0 & 0 & 0 & 0 & 0 \\
1 & 1 & 104 & 0,1 & 104 & 0,1 & 104 \\
2 & 2 & 105 & 1 & 208 & 0,1 & 208 \\
3 & 3 & 105 & 1 & 209 & 1 & 312 \\
4 & 4 & 107 & 1,2 & 209 & 1 & 313 \\
5 & 5 & 106 & 1 & 211 & 1 & 313 \\
\hline \multicolumn{8}{c}{ Source: Research processing results, 2020 }
\end{tabular}

Based on Table 7, the optimal solution of the three stages of completion of Forward Recursive Dynamic Programming is $\mathrm{X}_{1}{ }^{*}=2, \mathrm{X}_{3}{ }^{*}=2, \mathrm{X}_{3}{ }^{*}=1$. Then then look back at the optimal number of workers that were plotted previously in Table 8.

Table 8. Number of Shift Worker

\begin{tabular}{|c|c|c|c|}
\hline \multirow{2}{*}{ Day } & \multicolumn{3}{|c|}{ Number of Shift Worker } \\
\hline & $\mathrm{X} 1 *$ & $\mathrm{X} 2 *$ & $\mathrm{X} 3{ }^{*}$ \\
\hline 0 & 0 & 0 & 0 \\
\hline 1 & 104 & 104 & 104 \\
\hline 2 & 105 & 104 & 102 \\
\hline 3 & 105 & 103 & 103 \\
\hline 4 & 107 & 105 & 99 \\
\hline 5 & 106 & 103 & 102 \\
\hline
\end{tabular}

Based on Table 8, the optimal solution of the three stages of completion of Forward Recursive Dynamic Programming is $\mathrm{X}_{1}{ }^{*}=2, \mathrm{X}_{3}{ }^{*}=2, \mathrm{X}_{3}{ }^{*}=1$. Then the allocation of labor for each shift at PT. XYZ based on the calculation of Forward Recursive Dynamic Programming is Shift $1=105$ people, Shift $2=$ 104 people, and Shift $3=104$ people. In addition, the total number of workers that must be owned by PT. $\mathrm{XYZ}$ so that optimal work based on the calculation of Forward Recursive Dynamic Programming is 313 people.

2) Backward Recursive Settlement Procedure, performed using forward or backward recursive calculations. Then it will start from the first stage $(n=3)$. Since starting from the first stage, $n=3$, the optimum value for the first stage can be seen immediately by allocating all available $s 3$ to shift 3 :

a) Optimum Value for Stage $3(\mathrm{n}=): f_{3}\left(S_{3}, X_{3}\right)=C_{3}\left(X_{3}\right)+f_{4}^{*}\left(S_{3}-X_{3}\right)$, in where [29, 30]:

$f_{4}^{*}\left(S_{3}-X_{3}\right)=0$, then it can be assumed:

$f_{4}^{*}\left(S_{3}-X_{3}\right)=C_{3}\left(X_{3}\right)$, so that:

$X_{3}^{*}=S_{3} \operatorname{dan}_{3}^{*}\left(S_{3}\right)=C_{3}\left(X_{3}\right)$.

Table 9. Completion of stage $3(n=3)$ recursive backward

\begin{tabular}{ccc}
\hline $\mathrm{S} 3$ & $\mathrm{~F} 3 *(\mathrm{~S} 3)$ & $\mathrm{X} 3$ \\
\hline 0 & 0 & 0 \\
1 & 104 & 1 \\
\hline $\mathrm{S} 3$ & $\mathrm{~F} 3 *(\mathrm{~S} 3)$ & $\mathrm{X} 3$ \\
\hline 2 & 102 & 2 \\
3 & 103 & 3 \\
4 & 99 & 4 \\
5 & 102 & 5 \\
\hline
\end{tabular}

Now the calculation moves forward starting from the previous stage $(\mathrm{n}=3)$. Here to determine $s 2$, it is necessary to calculate and compare $f 2(s 2, x 2)$ for alternative values of $x 2$, namely $s 2=0,1, \ldots, s 2$. 
b) Optimum Value for Stage $2(\mathrm{n}=2)$ : The calculations required for the case are summarized. The next calculation is continued for $S=4$ and $S=5$, until all the calculations for the $n=2$ stages are complete, as in Table 10. the accumulated calculations below:

c)

Table 10. Results of calculation stage 2 backward recursive

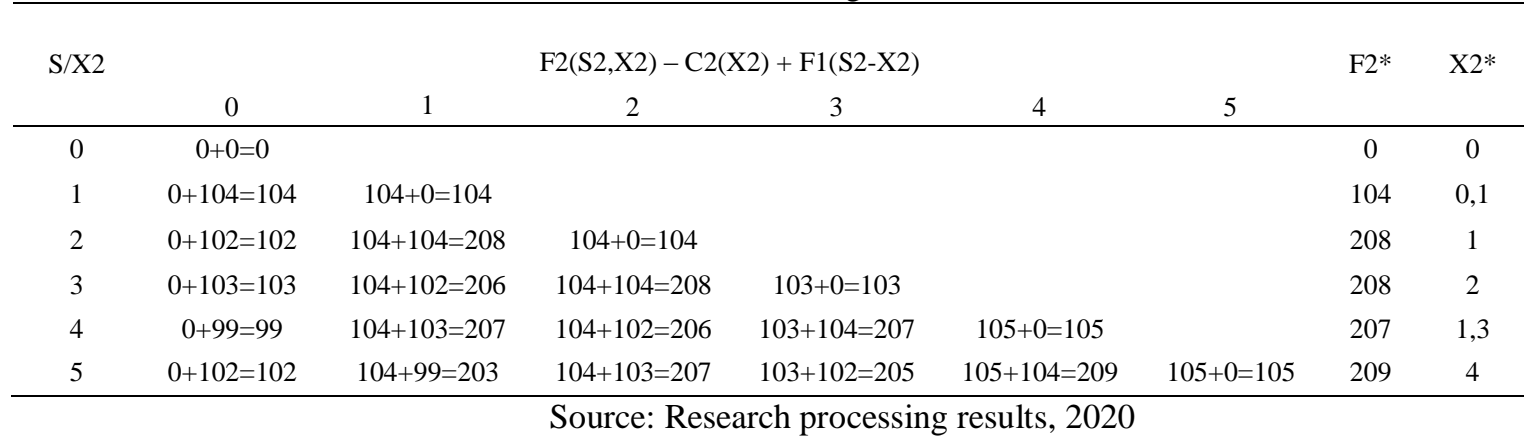

d) Optimum Value for Stage $1(\mathrm{n}=1)$ : The calculations required for the kasus1 case are summarized. The next calculation is continued for $S=4$ and $S=5$, until all calculations for the $\mathrm{n}=1$ phase are complete, as in Table 11. the accumulated calculations below:

Table 11. Results of calculation stage 1 backward recursive

\begin{tabular}{|c|c|c|c|c|c|c|c|c|}
\hline \multirow{2}{*}{$\mathrm{S} / \mathrm{X} 2$} & \multicolumn{6}{|c|}{$\mathrm{F} 3(\mathrm{~S} 3, \mathrm{X} 3)-\mathrm{C} 3(\mathrm{X} 3)+\mathrm{F} 1(\mathrm{~S} 3-\mathrm{X} 3)$} & \multirow{2}{*}{$\mathrm{F} 2 *$} & \multirow{2}{*}{$\mathrm{X} 2 *$} \\
\hline & 0 & 1 & 2 & 3 & 4 & 5 & & \\
\hline 0 & $0+0=0$ & & & & & & 0 & 0 \\
\hline 1 & $0+104=104$ & $104+0=104$ & & & & & 104 & 0,1 \\
\hline 2 & $0+208=208$ & $104+104=208$ & $105+0=105$ & & & & 208 & 0,1 \\
\hline 3 & $0+208=208$ & $104+208=312$ & $105+104=209$ & $105+0=105$ & & & 312 & 1 \\
\hline 4 & $0+207=207$ & $104+208=312$ & $105+208=313$ & $105+104=209$ & $107+0=107$ & & 313 & 2 \\
\hline 5 & $0+209=209$ & $104+207=313$ & $105+209=313$ & $105+208=313$ & $107+104=211$ & $106+0=106$ & 313 & 2,3 \\
\hline
\end{tabular}

e) So based on the results of the calculation of the Advanced Recursive Dynamic Programming method, the accumulated results can be seen in Table 12 .

Table 12. The accumulated result of backward recursive optimal solutions

\begin{tabular}{ccccccc}
\hline \multirow{2}{*}{$\mathrm{S}$} & \multicolumn{3}{c}{ Morning } & \multicolumn{2}{c}{ Afternoon } & \multicolumn{2}{c}{ Evening } \\
& $\mathrm{X} 1 *$ & $\mathrm{~F} 1 *(\mathrm{X} 1)$ & $\mathrm{X} 2 *$ & $\mathrm{~F} 2 *(\mathrm{X} 2)$ & $\mathrm{X} 3 *$ & $\mathrm{~F} 3 *(\mathrm{X} 3)$ \\
\hline 0 & 0 & 0 & 0 & 0 & 0 & 0 \\
1 & 0,1 & 104 & 0,1 & 104 & 1 & 104 \\
2 & 0,1 & 208 & 1 & 208 & 2 & 102 \\
3 & 1 & 312 & 2 & 208 & 3 & 103 \\
4 & 2 & 313 & 1,3 & 207 & 4 & 99 \\
5 & 2,3 & 313 & 4 & 209 & 5 & 102 \\
\hline
\end{tabular}

Source: Research processing results, 2020

Based on Table 12, the optimal solution of the three stages of completion of Backward Recursive Dynamic Programming is $\mathrm{X}_{1}{ }^{*}=2, \mathrm{X}_{3}{ }^{*}=2, \mathrm{X}_{3}{ }^{*}=1$. Then then look back at the optimal number of workers that were plotted previously in Table 13. Based on Table 13. the optimal solution of the three stages of completion of Forward Recursive Dynamic Programming is $X_{1}{ }^{*}=2, X_{3}{ }^{*}=2, X_{3}{ }^{*}=1$. Then the allocation of labor for each shift at PT. XYZ based on the calculation of Backward Recursive Dynamic Programming is Shift $1=105$ people, Shift $2=$ 104 people, and Shift $3=104$ people. In addition, the total number of workers that must be owned by PT. XYZ so that optimal work based on the calculation of Forward Recursive Dynamic Programming is 313 people. 
Table 13. Number of shift worker

\begin{tabular}{cccc}
\hline \multirow{2}{*}{ Day } & \multicolumn{3}{c}{ Number of Shift Worker } \\
& X1* & X2* & X3* \\
\hline 0 & 0 & 0 & 0 \\
1 & 104 & 104 & 104 \\
2 & 105 & 104 & 102 \\
3 & 105 & 103 & 103 \\
4 & 107 & 105 & 99 \\
5 & 106 & 103 & 102 \\
\hline \multicolumn{4}{c}{ Source: (Research Processing Results, 2020) }
\end{tabular}

The amount of labor required according to the analysis of the Dynamic Programming method with forward recursive and backward recursive calculations is the same, namely:

1) Morning shift $=105$ people

2) Day shift $=104$ people

3) Night shift $=104$ people

The number of workers generated through the calculation of the Dynamic Programming method is the allocation of labor that is estimated to be maximum and optimal who can work every day. If this calculation is applied to the production process, it will provide benefits for the company, where the labor can be allocated to each shift precisely according to the number of lens orders available [30, 31]. Labor that can be used or worked every day at PT. XYZ numbered 311 people, but after being calculated using the Dynamic Programming Method, the workforce allocated should be 313 people. Less than 2 people every week. This means that PT. XYZ can allocate 2 more workers to work at the company. With the addition of a workforce of 2 people, it will make the production process at PT. $\mathrm{XYZ}$ is more productive and optimal. Workers can work in accordance with their portion (effectively), they can devote all their abilities and dedication optimally, so that the number of lens orders that come from customers can be completed properly by the workforce (effective). And with the optimization of the allocation of labor in each shift at PT. XYZ will increase productivity and efficiency in the production process, because with a balance in every element of production, or the absence of a lack or excess of workforce, it will increase productivity which is good for the condition of the company itself.

\section{Conclusion}

PT. XYZ has 3 shifts with five working hours each week. Analysis of the Optimization of Dynamic Programing in the practice of allocating labor for each shift at PT. XYZ can be optimized if the allocation of workers is added by 2 people, from the initial number of 311 people, it turns out that after being analyzed using the Dynamic Programing method, the allocation of the number of workers in each shift can only be optimal or effective according to the number of orders, as well as the portion of the workforce if the number the workforce allocation is 313 people. Therefore, PT. XYZ can recruit 2 new workers, to optimize the dedication of each workforce, and to cultivate a positive work spirit, without any shadow of emphasizing target achievement. Because through the allocation of workers using Dynamic Programing, the target of each order that comes will be used as a basis (source) in the process of allocating the number of workers. So that we can be sure the number of worker allocations will be appropriate/effective or right on target, as well as efficient or effective with the number of orders that come to PT. XYZ, without any frills for workers who have to issue their abilities to their limits just to fulfill the target order and ignore their safety, health and humanity aspects.

It is recommended that companies try to apply the Dynamic Programing method because by using the Dynamic Programing method, the results of allocating the number of workers in each shift can be optimal according to the number of orders, and according to the ability of each worker. With the results of the discussion above, the addition of 2 workers will be able to make the portion of work of each workforce appropriate, or not exceed the limit, so that it can have an impact on reducing fatiq (fatigue), and all of that will lead to labor productivity, because they work accordingly. the portion it should be. 


\section{Acknowledgment}

Gratitude goes to the Chancellor, Dean, Study Program Coordinator at Singaperbangsa Karawang University and PT. XYZ who have supported and helped this research to succeed.

\section{Appendix}

Results of Normality Test Processing with the help of SPSS Software Version 23.

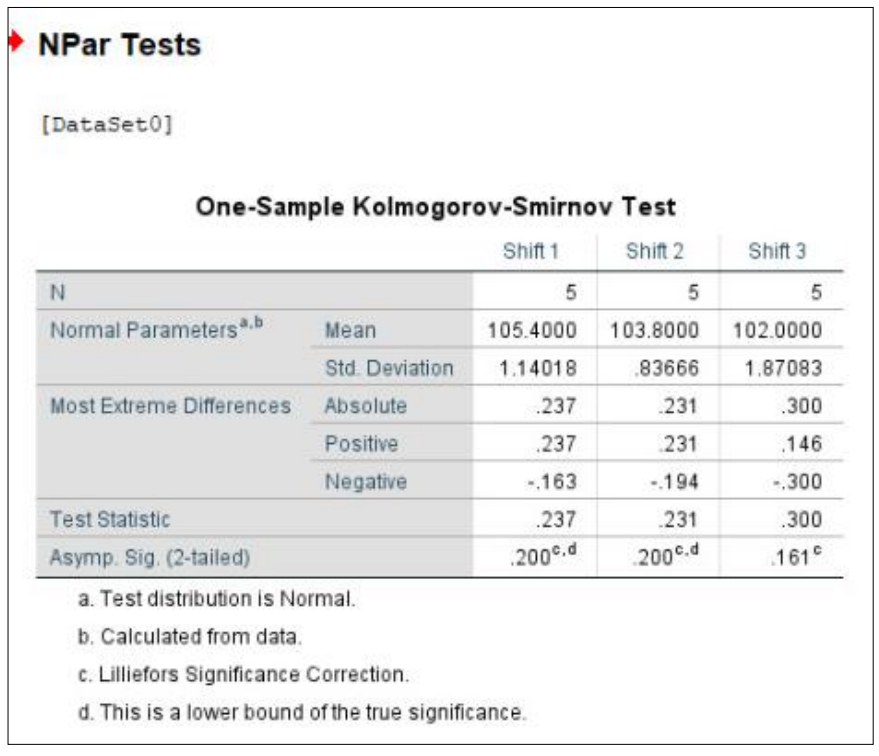

\section{References}

[1] Aminuddin, Prinsip-Prinsip Riset Operasi, Jakarta: Erlangga, 2005.

[2] D. P. Bertsekas, Dynamic Programming and Optimal Control Volume 1, North America: Athena Scientific, 2017.

[3] S. Mulyono, Riset Operasi, Jakarta: Mitra Wacana Media, 2017.

[4] H. Sarjono, Aplikasi Riset Operasi, Jakarta: Salemba Empat, 2010.

[5] A. Rangkuti, 7 Model Riset Operasi dan Aplikasinya, Surabaya: Brilian Internasional, 2013.

[6] Subijanto, "Peran Negara dalam Hubungan Tenaga Kerja Indonesia," Jurnal Pendidikan dan Kebudayaan, vol. XVII, no. 6, pp. 705-718, 2011.

[7] A. Wijaya, Pengantar Riset Operasi, Jakarta: Mitra Wacana Media, 2014.

[8] J. Supranto, Riset Operasi untuk Pengambilan Keputusan, Jakarta: Rajawali Pers, 2014.

[9] B. A. Noer, Belajar Mudah Riset Operasional, Yogyakarta: Andi Publisher, 2011.

[10] W. B. Powell, Approximate Dynamic Programming (Solving the Cursed of Dimensional), New Jersey: Wiley, 2011.

[11] J. K. Siang, Riset Operasi dalam Pendekatan Algoritmis, Yogyakarta: Andi Publisher, 2015.

[12] R. Aurachman, "Pemrograman Dinamis," 29 September 2014. [Online]. Available: http//www.you.be.com. [Accessed 12 October 2020].

[13] M. Agus, Hukum Ketenagakerjaan Indonesia Dinamika dan Kajian Teori, Bogor: Ghalia Indonesia, 2010, p. 7.

[14] A. Gunawan, "Analisis Program Dinamik dan Penerapannya pada Masalah Pengaturan Jumlah Tenaga Kerja Tiap Shift pada Rumah Sakit," Departemen Pendidikan Universitas Sumatra Utara, Sumatra Utara, 2018.

[15] H. Yunus, Helmi and S. Martha, "Metode Program Dinamis pada Penyelesaian Traveling Salesman Problem," Buletin Ilmiah Mat. Stat. dan Terapannya (Bimaster), vol. IV, no. 3, pp. 329-336, 2015.

[16] K. S. Saragih, N. H. Harahap and J. S. Sitorus, "Analisis Transportasi Pengangkutan Sampah di Kota Medan Menggunakan Dynamic Programming," Jurnal Informatika, vol. VII, no. 2, pp. 126-130, 2020.

[17] A. R. Lufafi, W. Y. Widiarti and E. Hidayah, "Optimasi Pola Tata Tanam di Daerah Irigasi 
Gembleng Kabupaten Banyuwangi Menggunakan Program Dinamik," Jurnal Rekayasa Sipil dan Lingkungan, vol. IV, no. 1, pp. 11-21, 2020.

[18] E. A. Rachma, "Optimasi Perencanaan Produksi dengan Menggunakan Model Sistem Dinamik di PT X," Jurnal Optimasi Teknik Industri, vol. II, no. 1, pp. 36-42, 2020.

[19] Novitasari and M. I. Mas'ud, "Integrasi Linier Programming dan Program Dinamik untuk Menentukan Jumlah Produksi Kopi yang Optimum di UD. Gading Mas," Journal Knowledge Industrial Engineering (JKIE), vol. VII, no. 1, pp. 30-37, 2020.

[20] S. Maslihah, "Program Dinamik untuk Pendistribusian Komoditi Kerupuk '9 Berlian' Wates," Jurnal At-Taqqaddum, vol. X, no. 1, pp. 81-94, 2018.

[21] A. R. Brahmana, Poerwanto and T. S. Sinaga, "Optimasi Produksi dengan Program Dinamis pada Pabrik Fractination and Refinery Factory (FRF) PT. XYZ," e-Jurnal Teknik Industri FT USU, vol. III, no. 4, pp. 49-54, 2013.

[22] P. Delfianda, H. Komalig and T. Manurung, "Optimalisasi Biaya Total Perencanaan dan Pengendalian Persediaan Menggunakan Program Dinamik," Jurnal JdC, vol. IV, no. 1, pp. 1-8, 2015.

[23] Wamiliana, D. Kurniasari and F. Rokhman, "Implementasi Metode Dynamic Programming pada Aplikasi Penentuan Jarak Minimum," Jurnal Komputasi, vol. I, no. 10-14, 2013.

[24] D. Pratiwi, Syaripuddin and Haeruddin, "Perencanaan Produksi Menggunakan Model ARIMA dan Pengendalian Persediaan Menggunakan Program Dinamik untuk Meminimumkan Total Biaya (Studi Kasus: Produksi Amplang UD. Usaha Devi)," Jurnal Eksponensial, vol. IV, no. 1, pp. 25-32, 2013.

[25] K. D. P. Hapsari, S. Wahyudi and S. D. Surjanto, "Identifikasi Tingkat Inflasi Nasional Berdasarkan Cost Push Inflation Menggunakan Metode Pemrograman Dinamis," SPECTA Journal of Technology, vol. IV, no. 3, pp. 80-90, 2020.

[26] R. T. Kusumah and A. Ilmaniati, "Optimasi Persediaan Pupuk Non-Subsidi Menggunakan Program Dinamis Model Inventory (UD. Barokah)," JMTSI Jurnal Media Teknik dan Sistem Industri, vol. III, no. 2, pp. 67-72, 2019.

[27] B. Sesetyo and G. F. Laxmi, "Model Dinamis Pengelolaan Air Bersih Terpaddu di Kota Bogor," Jurnal Krea-TIF, vol. V, no. 1, pp. 35-47, 2017.

[28] A. Rangkuti, "Penerapan Model Dinamik Probabilistik pada Produksi Kendaraan Bermotor dalam Negeri Tahun 2009-2013," JMSK Jurnal Matematika, Statistika \& Komputasi, vol. XI, no. 1, pp. 816, 2014.

[29] M. T. Maulani and A. Sabar, "Optimalisasi Pengusahaan Hidroelektrik Riam Kanan dalam Rangka Memenuhi Kebutuhan Air Baku SPAM Kawasan Regional Banjarbaru," Jurnal Teknik Lingkungan, vol. XVI, no. 1, pp. 1-18, 2020.

[30] T. A. Putra, S. S. Riskijah and J. Setiono, "Optimasi Jumlah Operator Alat Berat pada Pekerjaan Struktur Proyek Apartemen X Menggunakan Dynamic Programming Method," JOS - MRK Jurnal Online Skripsi - Manajemen Rekayasa Kontruksi, vol. I, no. 1, pp. 7-15, 2020.

[31] G. I. Sampurno, E. Sugiharti and Alamsyah, "Comparison of Dynamic Programming Algorithm and Greedy Algorithm on Integer Knapsack Problem in Freight Transportation," Scientific Journal of Informatics, vol. V, no. 1, pp. 40-49, 2018. 